Dialectologia 27 (2021), 1-31.

ISSN: 2013-2247

Received 5 Agust 2019.

Accepted 21 October 2019.

DOI: 10.1344/DIALECTOLOGIA2021.27.1

\title{
A TONAL IDENTIFICATION OF YORUBA DIALECTS
}

\author{
Kolawole ADENIYI \\ Obafemi Awolowo University * \\ kola.adeniyi@oauife.edu.ng
}

\begin{abstract}
This article studies variations in the realisation of contour tones in Oyo, Ibadan, Ife, Igbomina, ljebu, Ijesa, Ilorin, and Onko dialects of Yoruba and reports that the dialects exploit different dimensions of contour tone realisation to distinguish themselves. Ife, Igbomina and ljesa dialects reduce the frequency of contour tones via high tone lowering and contour levelling, whereas ljebu dialect multiplies contours in several ways. For instance, where the other dialects have $\mathrm{MH}$ and $\mathrm{HH}$ sequences, ljebu has LH [LR], which increases its frequency of contour tones. In addition, ljebu is the only dialect in which the M participates in contour tone formation whereby, ML sequence is realised MML. On the other extreme, Onko does not realise the falling contour at all. It is consequently argued that these dissimilarities between tonal contours are key indicators of dialectal variations among Yoruba dialects and they are more discernible than segmental and other grammatical indicators that have been more widely studied.
\end{abstract}

\section{Keywords}

Yoruba, dialectology, contour tone, pitch track, high tone lowering

\section{UNA IDENTIFICACIÓN TONAL DE LOS DIALECTOS YORUBA}

\section{Resumen}

Este artículo estudia las variaciones en la realización de tonos de contorno en los dialectos Yoruba: Oyo, Ibadan, Ife, Igbomina, Ijebu, Ijesa, Ilorin y Onko; y demuestra que los dialectos utilizan diferentes dimensiones de la realización de tonos de contorno para distinguirse. Los dialectos Ife, Igbomina e ljesa

\footnotetext{
* Department of Linguistics and African Languages, Obafemi Awolowo University, 220282, P. M. B. 013, lleIfe, Nigeria.
} 
reducen la frecuencia de los tonos del contorno a través de la disminución y nivelación del tono alto, mientras que el dialecto ljebu multiplica los contornos de varias maneras. Por ejemplo, donde los otros dialectos tienen secuencias $\mathrm{MH}$ y $\mathrm{HH}$, ljebu tiene $\mathrm{LH}[\mathrm{LR}]$, lo que aumenta su frecuencia de tonos de contorno. Además, ljebu es el único dialecto en el que la M participa en la formación del tono del contorno, por lo que la secuencia ML se realiza MML. En el otro extremo, Onko no realiza el contorno descendente en absoluto. En consecuencia, se argumenta que estas diferencias entre los contornos tonales son unos indicadores clave de las variaciones dialectales entre los dialectos yoruba y son más perceptibles que los indicadores segmentarios y otros indicadores gramaticales que han sido estudiados más ampliamente.

\section{Palabras clave}

Yoruba, dialectología, tono de contorno, representación del tono, descenso del tono alto

\section{Introduction}

A number of works have appeared in the literature on dialectology focusing on Yoruba. These works on Yoruba dialectology include Akinkugbe (1976), Adetugbo (1982), Lamidi (2002), Ayeomoni (2011), Fabunmi (2013), Adeniyi \& Bamigbade (2017) and Adeniyi (2018), among others. The volume of research in this area is justified because Yoruba is a dialect continuum comprising more than 40 dialects. However, with the exclusion of the Oyo dialect, being the closest to the standard form and having a fairly comprehensive linguistic description, the existing research works on the other dialects have focussed on isolated areas of grammar and segmental phonology, leaving a wide gap in the understanding of tonal behaviours across the dialect group. This gap is not limited to only Yoruba as Bougrine et al. (2018: 11) note that prosody-based dialectal studies are not yet well explored. This work therefore aims to carry out a cross-dialectal investigation on tone in selected dialects Yoruba in order to fill this gap.

This study therefore explores the various ways in which Yoruba dialects differ on the basis of tonal contours. This is with the aim of establishing a platform for tangibly characterising these dialects based on pitch modulation. The article is laid out in six sections; the general background to Yoruba language is presented in section 2, with an outline of the method in section 3. Dialect-by-dialect data presentation on the tonal peculiarities of each dialect is done in section 4. Section 5 contains main discussions of 
the tonal contour variation among the dialects studied and the work is concluded in section 6 .

\section{Background}

\subsection{Dialectology}

Yoruba dialectology has been largely studied from syntactic and lexical perspectives. Aremo (2012: 2) notes that each of the regional dialects of Yoruba is "identified by a particular set of words and grammatical structures, and a distinctive pronunciation". However, the study of the "pronunciation" aspect (which is the phonetic/phonological aspect) is limited to segmental elements of consonants and vowels (see for instance Akinkugbe 1976; Adetugbo 1982; Ayeomoni 2011; Fabunmi 2013 among others), which means that the tonological aspect is largely left to undocumented impression. Specifically, Olumuyiwa (2009) examines the nature of the subject-marking element of High Tone Syllable (HTS) across Ekiti, Ife, ljesa and Moba dialects and reports that whereas the HTS gets deleted in Ekiti dialect, it assimilates to the vowel preceding it in Ife, Ijesa and Moba dialects.

Adeniyi \& Bamigbade (2017) study the speech of a Yoruba preacher who deploys the Ibadan dialect in his preaching in order to achieve humorous effects. Prominent among his ways of achieving this is his manipulation of the falling and rising contour tones by exaggerating them such that his speaking sounds extremely and comically Ibadan to the speakers of other dialects of the language.

Extensive dialectal studies of some other languages abound in the literature (see Haraguchi 1979 and Yip 1980, for instance). A recent one is Friedman (2017), who studies phonological, morphological, and lexical features across seven dialects of Arli, all of which are spoken in Skopje, the capital of Macedonia. Using a hybrid method and sampling 60 speakers with ages ranging from 20 to 80, Friedman (2017) studies the emblematic 
features of the seven dialects and reports that the dialects are converging in some aspects and diverging in others.

From the speech modelling perspective, Etman \& Beex (2015) did a survey of the state of research on dialect identification, drawing from linguistic, sociolinguistic and computational studies. After sampling 17 databases and at least 12 methodologies, they observe that research on dialect identification has been hampered by a lack of data as well as the need for extended time of analysis. The survey also reveals that most studies on dialect identification have focused on vowels and consonants and that most of the works have focused on English, Arabic, and Asian languages. These show the need to do more on African languages, and also to pay attention to tone, since it is an integral part of the lexical configuration of African tone languages.

Since many research works suggest that consonants, vowels, phonotactics, morphology and grammars of the different dialects are relatively similar (Olumuyiwa 2009; Ayeomoni 2011; Fabunmi 2013 etc.), it becomes necessary to investigate the place of tone in the perceptual identification of Yoruba dialectal variations. This is more so as dialect variation is said to be largely phonetic or prosodic (Bougrine, Cherroun \& Ziadi (2018: 10). Although, La Velle (1974), Connell \& Ladd (1990) and a host of others have carried out experimental studies on Yoruba tone, the current research is innovative in that it is cross-dialectal with the aim of outlining dialectal tonal discrimination, it incorporates experiments into the instrumentation, and it seeks to answer lingering questions in Yoruba tone system.

\subsection{Yoruba}

Yoruba is a West Benue-Congo language spoken by about $30,000,000$ people in southwestern Nigeria (Oyetade 2011). It is also spoken as a native language in the Republic of Benin, Togo, Cote d'Ivoire, Ghana, Sierra Leone, Brazil and Cuba (Adetugbo 1982; Oyetade 2011; Fabunmi 2013). Within Nigeria, Yoruba dialects are grouped along geographical lines viz Northwest Yoruba (NWY), Southeast Yoruba (SEY), Central Yoruba (CY), Northeast Yoruba (NEY) and Southwest Yoruba (SWY) (Fabunmi 2013). The standard form of Yoruba (SY) was initially based on the Oyo dialect, but it has now diverged so 
Dialectologia 27 (2021), 1-31.

ISSN: 2013-2247

much from it that SY is now regarded as an abstraction spoken only in public domains and in education.

\subsection{Tone System of Standard Yoruba}

Yoruba operates three tone levels, high $(\mathrm{H})$, mid $(\mathrm{M})$, and low $(\mathrm{L})$ tones (Bamgbose 1990). This is seen in the minimal sets in (1-2) where each set is distinguishable only by tone, and this indicates the lexical position of the three tone levels in the language.
a. Sán "to cut grass"
b. San "to bite"
c. Sàn "watery"

(2)
a. Igbá "calabash"
b. Igba "two hundred"
c. Igbà "rope for climbing palm trees"

More specifically, $\mathrm{H}$ is phonetically realised as a rising contour after $\mathrm{L}$ (3a). Conversely, L is realised as a falling contour after H (3b) (Connell \& Ladd 1990; Akinlabi 2004).
a. ìgbă "garden egg"
b. agbúngbû "place name"

The language also has the downdrift and downstep phenomena (Connell \& Ladd 1990; Adeniyi 2009). In downdrift, a non-initial phonetic L pulls down $M$ and $H$ tones following it in height (4), while in downstep (DS) the height of $\mathrm{M}$ and $\mathrm{H}$ tones is pulled down by preceding non-initial $L$ that is not present phonetically. Notice that in comparing items to the left and right of the arrows in (5a-b) vowel elision takes off the vowels in parentheses along with their low tone leaving the tones on the TBUs immediately after the lost segments lowered (indicated by the down arrow). Closely related to DS is the 
Assimilated Low Tone phenomenon, by which, where the downstepped tone is $\mathrm{H}$ as we have in (5b), it is realised as a rising tone (Bamgbose 1967), which is considered the primary marker of ALT. Another marker of ALT is that the $\mathrm{H}$ preceding DS is realised as a falling tone (Adeniyi 2009).

$$
\text { àgbàdo "corn" }
$$
a. sé iṣẹ́ (ộ)kan ni? $\rightarrow$ séșẹe 'kan ni? “Is it one job?”
b. ó fẹ́ (ì)gbá $\rightarrow$ ó fẹ́ `gbá "he wants garden egg"

Yoruba also has the tone raising phenomenon by which $\mathrm{H}$ is raised by a following $\mathrm{L}$ (Laniran 1992; Laniran \& Clements 2003). By this the high tone in (3b) above will be realised on a level higher than the usual high because the tone immediately following it is L. Yoruba tonology is also affected by wide-spread consonant deletion in the language. By this, the consonant between two vowels bearing different tones may be elided and the vowels left in hiatus with their tones often appearing like contrastive contours. Examples (6a-b) below are from Bamgbose (1990: 71-74).
a. Èdúdú $\rightarrow$ èédú "charcoal”
b. Jọ̀wọ́ $\rightarrow$ jọọ̣ "please"

\section{Method}

This study adopts an instrumental approach as the primary method. This makes it possible to concretize the abstract and often elusive nature of tone. The study covers eight dialects namely, Oyo, Ibadan, Ife, Igbomina, Ijebu, Ijesa, Ilorin, and Onko. These dialects are spread across Oyo, Ogun, Osun and Kwara states of Nigeria. Between three and five adult speakers were recorded in each dialect. To avoid interference from Standard Yoruba (SY), it was ensured that the participating speakers were those who still conducted everyday conversation in their dialects. Initial data were collected using a personally-compiled list of 800 words. These primary data were supplemented by data 
gathered from weekly radio programmes on Igbomina and Onko dialects as well as an Ibadan-dialect-based sermon series on Television and YouTube.

During data collection, each data item was repeated two to five times by each of the speakers, to ensure that there was no lack of acoustically usable token for each of the data items. Two recording methods were adopted; where recordings were done in the sound-proofed studio at Obafemi Awolowo University, data were recorded directly onto a computer laptop using PRAAT. This was supplemented by field recordings using the Zoom H1n digital voice recorder.

In determining what was worth accepting as valid data for this research, only pitch modulations perceptible by the ear were investigated. Usually, modulations perceptible by the ears were also acoustically visible; but if such is not acoustically significant, then it is taken as part of indications of threshold of contour significance in the dialects.

A number of assumptions underpin the analyses in this work. One of these is that the roles of grammar and intonation are not accorded particular attention since exactly the same utterances were used for comparison across the dialects. This means that whatever low-level syntactic effect there might be is assumed to affect all the dialects alike. Another assumption is that intonational downdrift is general to all the dialects and was not factored into the interpretation of results. Closely related to this is the assumption that each tone is relative to the others within its tone phrase or utterance. Duration and segmental alternations were also not factored into the interpretation of results in so far as they have no direct bearing on pitch realisation. ${ }^{1}$

As noted earlier, Standard Yoruba (SY) originally derived from Oyo dialect and in spite of the divergence of SY from it, it is still considered the closest to the standard form today. Hence, it is the first to be described in this article; it is thereafter used as reference for comparing the other dialects. For each dialect, a brief description is presented in so far as what has been reported of the standard form above is not repeated. ${ }^{2}$

\footnotetext{
${ }^{1}$ Note that for all the dialects, the vowels bearing contour tones are relatively longer than those bearing level ones. But as has been suggested, this was considered general and was not explored further.

${ }^{2}$ For this reason, the mid tone may appear not reported for some dialects; this is because it does not present marked characteristics in such dialects.
} 


\section{Data}

\subsection{Oyo}

To a large extent, the tone system of SY outlined in section 2.3 above represents that of Oyo dialect phonemically. However, there are particular phonetic details that characterise the contemporary Oyo dialect. In the normal environment for rising tone, the rise starts on a raised level, often within the $\mathrm{H}$ range and rises only slightly (7a-d; ègẹ in Figure 1).
a. è̀gẹ "cassava"
b. àbǔrô "younger brother/sister"
c. ìrọ̀lẹ̆ "evening"
d. òdòdǒ "flower"

A second realisation of $\widehat{\mathrm{LH}}$ rising tone exists in Oyo dialect; ${ }^{3}$ in this case, it begins within the L-range and goes into that of $\mathrm{H}$ when preceded by falling tone. Falling tone in this case is either a phonetically falling tone (8a-b) or $\mathrm{H}$ that falls as a result of ALT (8c-d). In this case, the falling tone falls only slightly on its TBU, but then causes a following rising tone to begin from the range of $L$ and rise to the range of the $H$. In position of downstepped $H(D S H)$, the DSH rises from the level of the $L$ (which is now floating but effects a falling effect on the preceding linked $\mathrm{H}$ ), but in final position, the rising tone is levelled and is realised rather as $\mathrm{L}$.
a. ológbô dǔdú "black cat"
b. alákân dǔdú "black crab"
c. ẹlẹ́ dă "creator"
d. mú ${ }^{\downarrow}$ kǔn "(to be) lame"

\footnotetext{
${ }^{3} \widehat{\mathrm{LH}}$ rising tone, rising contour, rising tone, and $\mathrm{R}$ are used interchangeably in this work.
} 


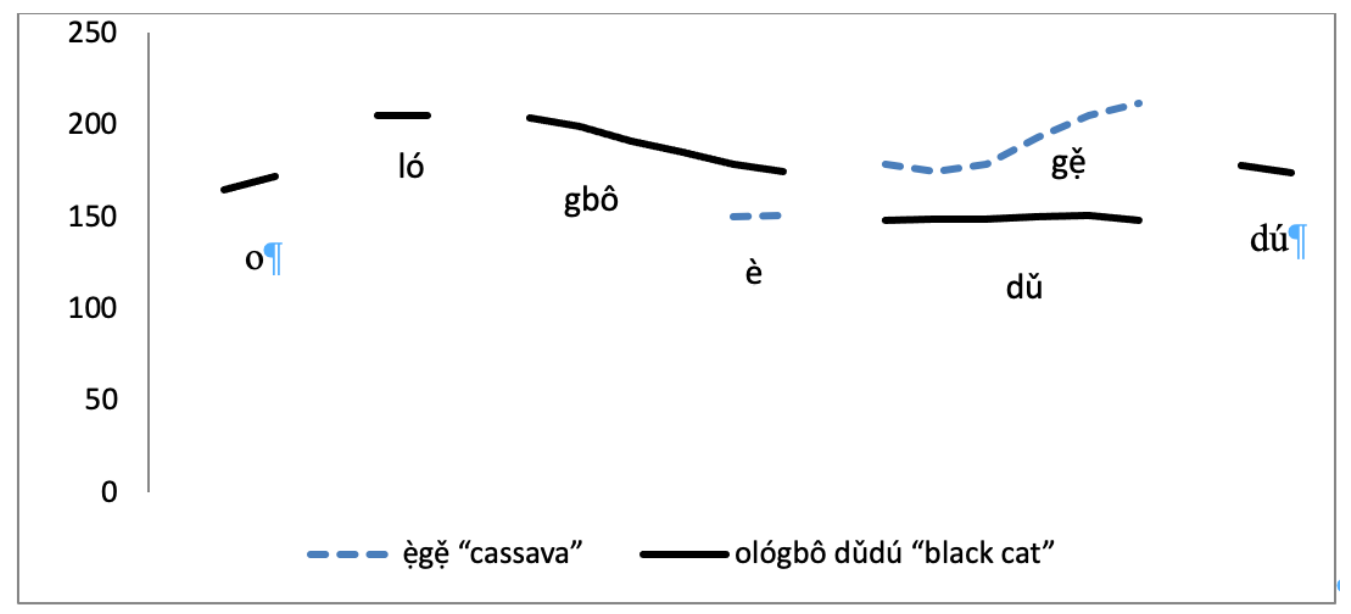

Figure 1. Comparative pitch of normal rising and levelled rising tone in Oyo dialect

The $\widehat{\mathrm{HL}}$ falling contour tends to start higher than previous $\mathrm{H}^{4}$ and only falls slightly (gbô in Figure 1). The fall tends to end within the $\mathrm{H}$ range. There is a second type of falling tone in Oyo dialect, and this is the short perceptual fall at the end of $\mathrm{H}$ when it is followed by a delinked L (9) or surface DSH (8c-d) (Bamgbose 1967; Adeniyi 2009).

gbọ́ (è)bè̀ $\rightarrow$ gbẹ́bệ "accept apology"

\subsection{Ibadan}

Generally, Ibadan dialect also has the $\mathrm{H}, \mathrm{M}$, and $\mathrm{L}$ level tones as well as the two contour tones $\widehat{\mathrm{LH}}$ and $\widehat{\mathrm{HL}}$ outlined for SY. The $\widehat{\mathrm{LH}}$ rising contour starts very low and only rises slightly (10a-d; Figure 2). The low starting point gives it an acute coloration attributable to the Ibadan dialect. In longer sequences containing $L-H$, the $L$ displaces the following $H$, rather than spread to it, and renders the $H$ floating. But the floating $H$ is enabled to make any linked $L$ following it to fall. In Figure 2 , we see the $L$ on è spread to gé and displacing the $\mathrm{H}$ underlyingly on that TBU, a process that eliminates the rising tone which would have resulted on gẹ. However, the now floating $\mathrm{H}$ still causes the $\mathrm{L}$ on the following TBU dûn to be realised as a falling tone. This is a case of contour tone levelling. More examples of tone-levelling are in (11a-d).

\footnotetext{
${ }^{4} \widehat{\mathrm{HL}}$ falling contour, falling tone, $\widehat{\mathrm{HL}}$ and $\mathrm{F}$ are used interchangeably.
} 
(10)
a. āràră "dwarf"
b. è̀gẹ "cassava"
c. àbǔrô "younger person"
d. àlǒ "folktale"

(11)

a. ẹ̀gẹ̆ dûn pǔpộ $\rightarrow$ ẹ̀gè̀ dûn pùpộ "cassava is so delicious"

b. ìlù lílù $\rightarrow$ ilù lilû "drumming"

c. sèbí Báyọ̀ ńbọ̀ $\rightarrow$ Șèbì Báyọ́ ňbộ "Bayo in coming?"

d. ìmọ́lè nínú ayé $\rightarrow$ ìmộlệ nìnú ayé

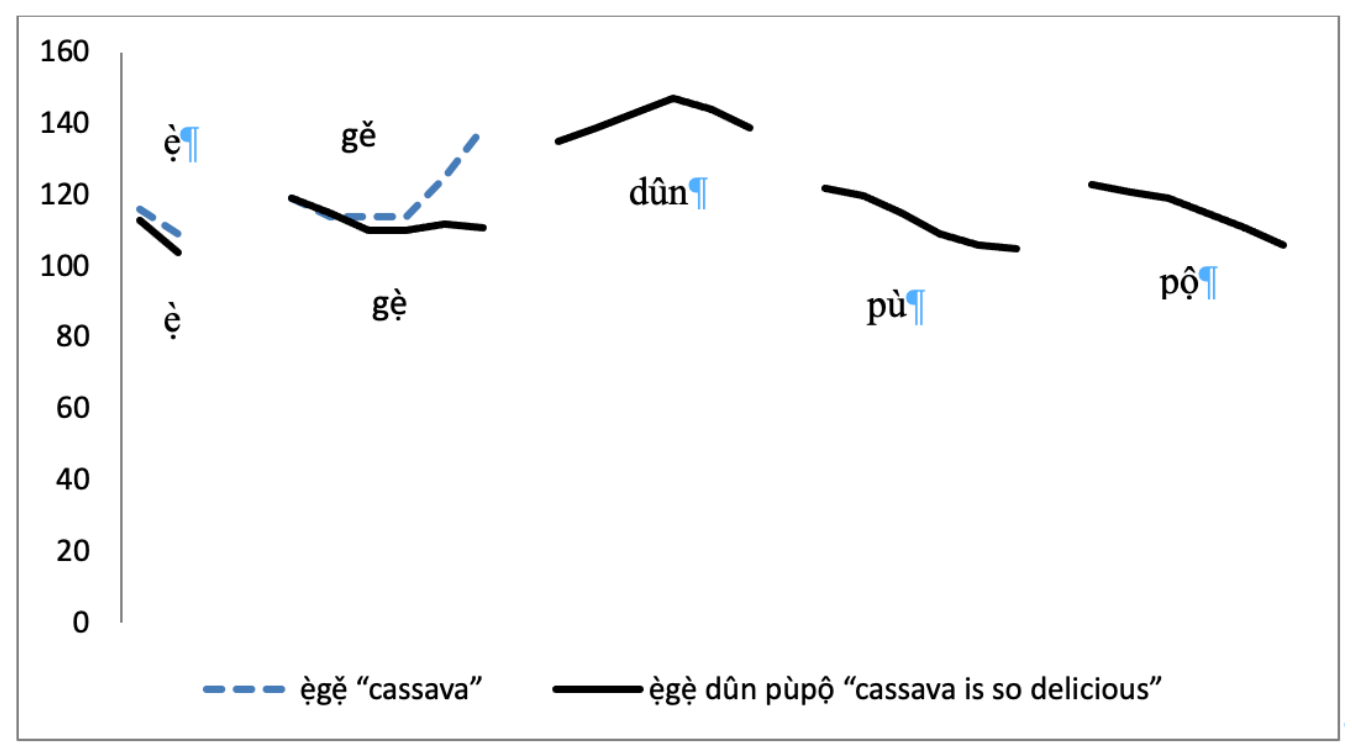

Figure 2. Rising tone-levelling in Ibadan dialect

The $\widehat{\mathrm{HL}}$ falling contour tone starts very high (often higher than the preceding $\mathrm{H}$ itself) and then falls only very slightly (12a-b). Its fall ends within the range of the $\mathrm{H}$ (way higher than M). Since the F has a short fall, it tends to be levelled in longer sequences. In (13a; Figure 3), rather than spread to a following $L$, the $H$ displaces that $L$ entirely and the $L$ is not phonetically realised. The only indication of the $L$ is that rather than being realised as $\mathrm{R}$ (an allotone of $\mathrm{H}$ ) the linked $\mathrm{H}$ after it is levelled to $\mathrm{L}$.
a. olóyê "chief"
b. ōlóńgbò "cat" 


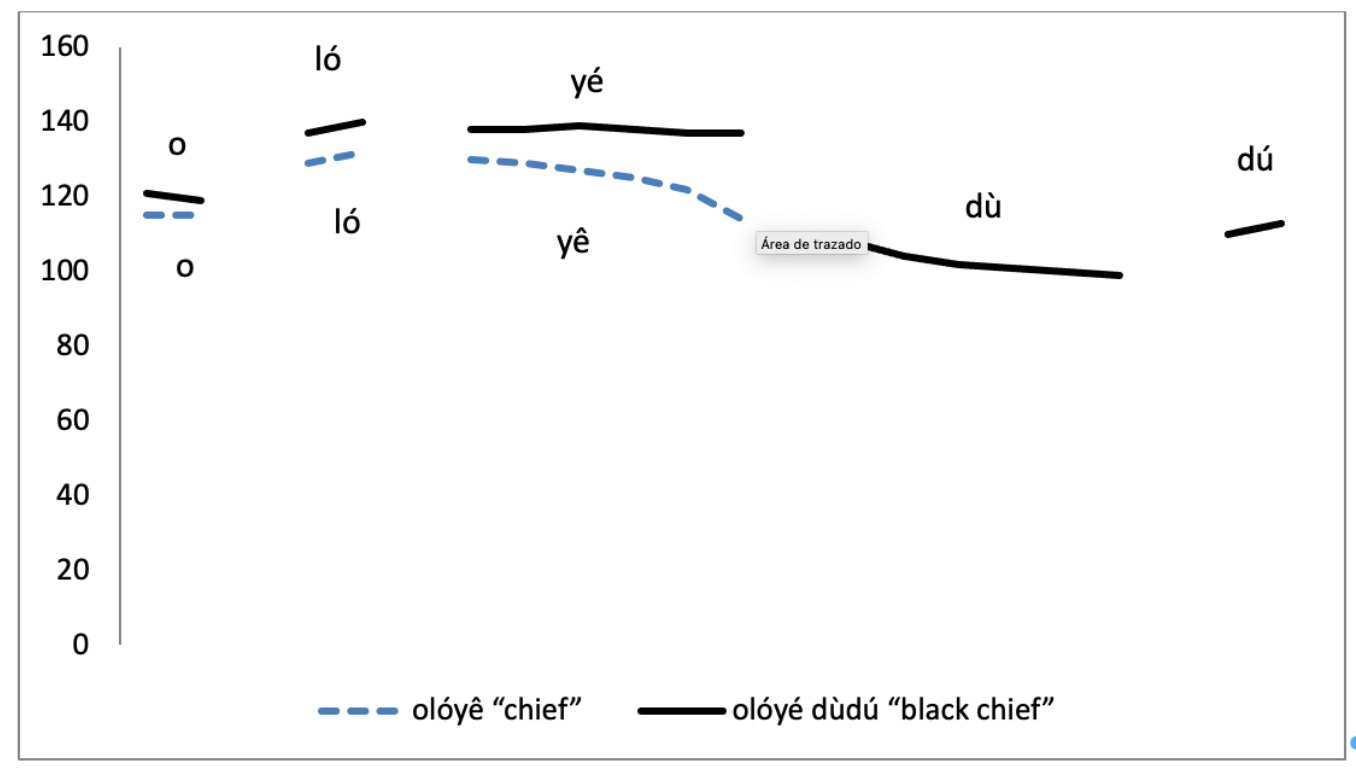

Figure 3. Falling tone levelling in Ibadan dialect
a. olóyè dúdú $\rightarrow$ olóyé dùdú "black chief"
b. Ādérẹ̀mí $\rightarrow$ Ādérẹ́mǐ "a personal name"

\subsection{Ife}

Ife dialect also aligns with SY tone system phonemically, but phonetically the contour tones are realised differently. In Ife dialect, the rising tone starts at the base of the $L$ range and rises to a level around the intersection between $M$ and $H$. At this level, it is often perceived as a rising $M$ in the natural flow of speech (14; Figure 4). Ife dialect also has the contour levelling phenomenon whereby the $L$ encroaches into the domain of following $\mathrm{H}$; and displaces it. But in a manner similar to Ibadan dialect the displaced $\mathrm{H}$ triggers the realisation of falling tone on a following TBU if that TBU is $L$ (15; ègẹ dûn in Figure 4). Observe that the second TBU of ègẹ dûn in Figure 4 does not rise while the corresponding one in ègẹ shows an upward glide in pitch on the same segment. In final position, the rising tone is realised as a level $L$ or as a fall.
a. ègẹ $\rightarrow$ ègẹ̆ "cassava"
b. bàbá $\rightarrow$ bàbă "father"
c. ìrộlẹ $\rightarrow$ ìộlẹ̆ "evening" 
a. ègẹ dùn $\rightarrow$ ègè̀ dûn "cassava is so delicious"

b. àgbálùmọ $\rightarrow$ àgbàlûmọ "cherry"

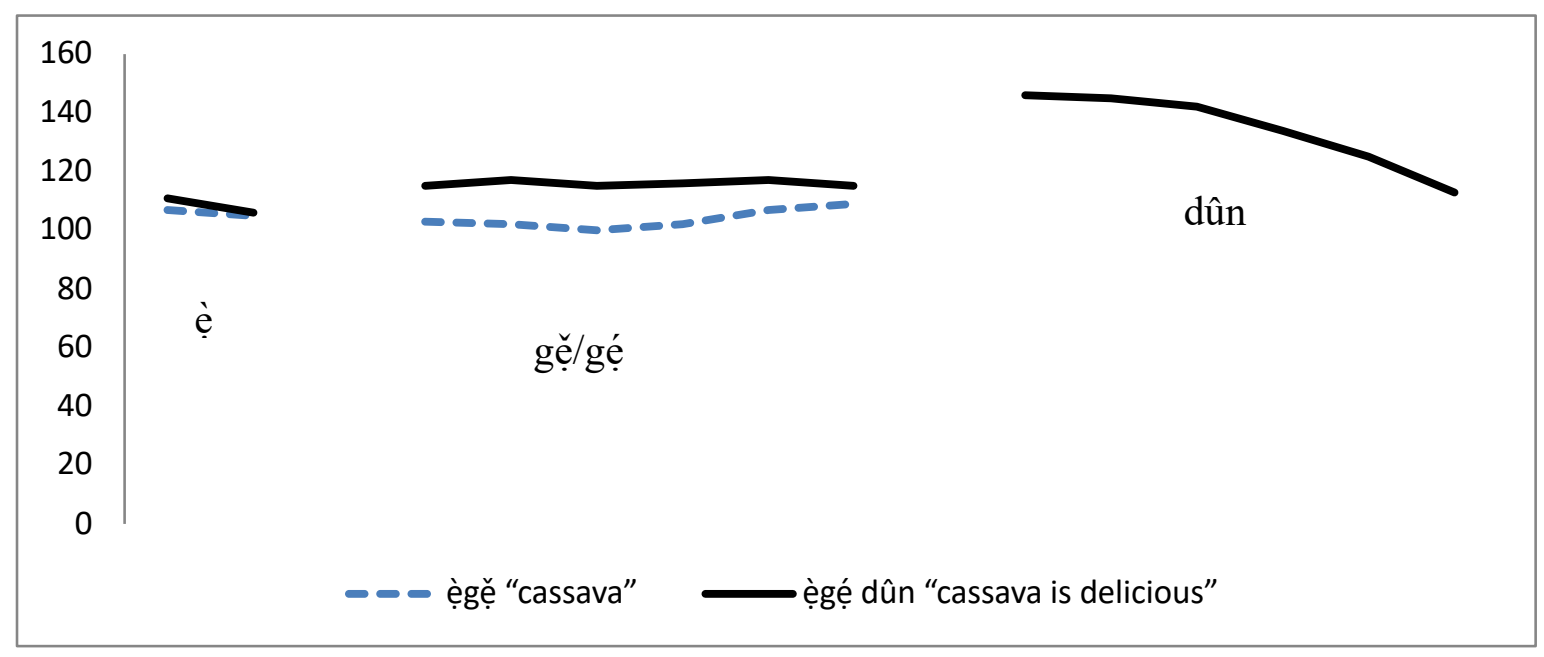

Figure 4. Rising tone vs rising tone levelling in Ife dialect

The falling tone in Ife dialect starts from the range of $\mathrm{H}$ and falls all the way to the Lrange (16a-b).
a. olóńgbô "cat"
b. olóyê "chief"

In the position of DS, the deleted (floating) L clearly lingers (with its segmental host only assimilating to the preceding vowel - not elided). This lingering $L$ prevents the spreading of $\mathrm{H}$ to a following linked L (17a-d; solid line in Figure 5). Observe that in the pitch curve for gbẹbẹ, there is no fall on bẹ; besides, even the onset of the L on that TBU is deep within the $L$ range.
a. rí (ộ)nà gbée gbà $\rightarrow$ rọ́nà gbée gbà "find a way out"
b. rí (è)yìn osù $\rightarrow$ rẹiyin osù "survive the month"
c. gbọ́ (à)ròyé $\rightarrow$ gbáròyě "listen to petitions"
d. gbộ ẹ̀ẹ̀ $\rightarrow$ gbẹ́bẹ̀ "accept plea" 


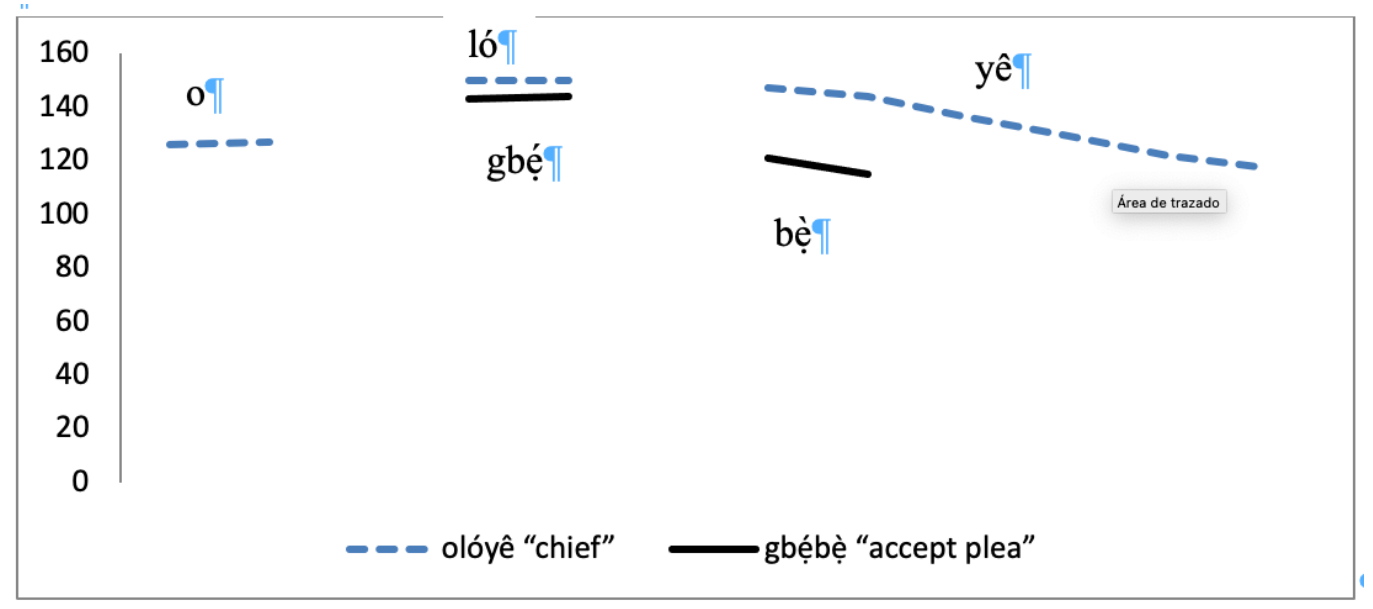

Figure 5. Falling tone vs F-blocking in Ife dialect

There is $\mathrm{H}$-lowering in Ife-dialect. When $\mathrm{H}$ is preceded by $\mathrm{L}$ and is at the same time followed by a floating $L$, it is lowered to $M(18 a-c)$. The consequence of this is that that $H$ does not rise as should be expected from the understanding of SY tonology. If there is a linked $L$ after the floating $L$, that $L$ also does not fall, thereby reducing the frequency of contour tones in the dialect (Figure 16; See an articulation of this process for Igbomina in Adeniyi 2018).
a. ̇ gbé (i)yàwǒ $\rightarrow$ igbeyàwǒ "wedding"
b. àbǔrô mú (ẹ)rìnlă $\rightarrow$ àbǔrô mẹrìnlǎ "14 younger ones"
c. à tì ní (ẹ)yìn $\rightarrow$ àtìlẹyìn "support"
d. ì dú (i)je $\rightarrow$ idije "competition"

\subsection{Igbomina}

Igbomina dialect is also similar to SY tonemically, but has its own variant phonetic realisations of the contour tones. Falling tone starts its fall from the base of the H-range and then falls significantly, but when followed by a non-low tone (Figure 6), the fall becomes significantly levelled in a way similar to Ife (19a-b). Observe that in Figure 6, the pitch curve on dûn begins from a low onset and its offset is still higher than that of yê; this pictorial levelling has significant perceptual print in the dialect. 
a. ìgbădûn gidi "real enjoyment"

b. ègě dûn pǔpộ "cassava is so delicious"

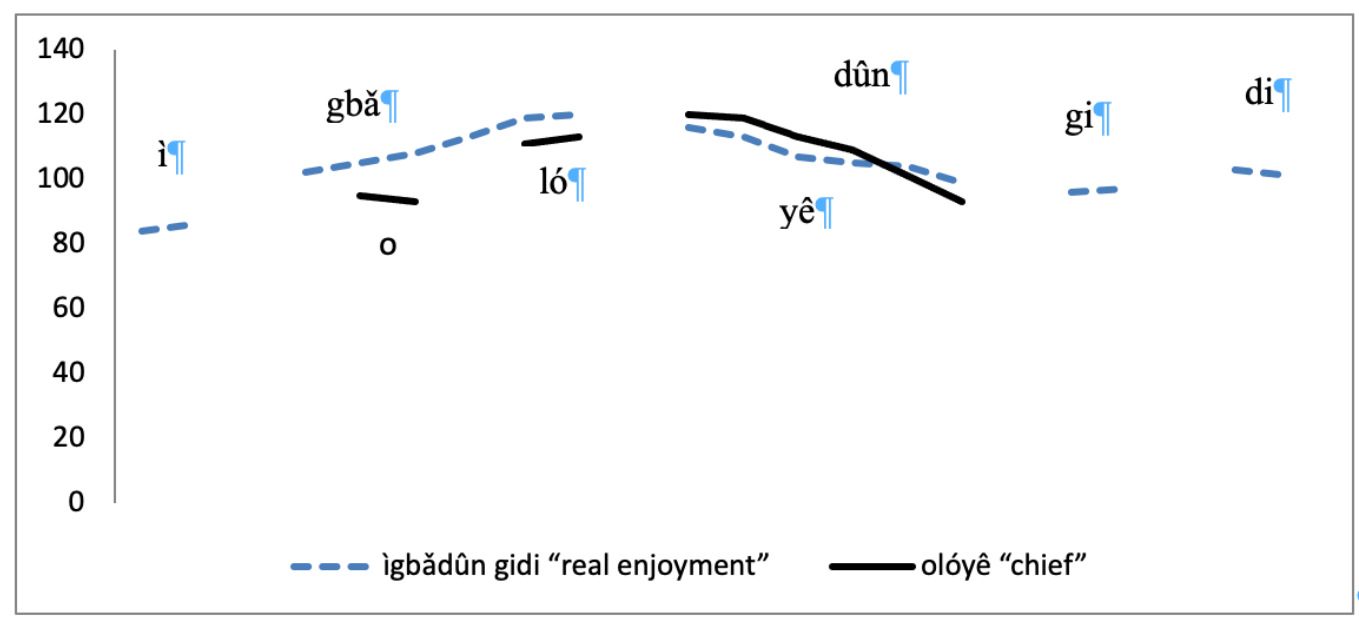

Figure 6. Falling contour vs. F-levelling in Igbomina dialect

The rising tone starts within the range of $\mathrm{H}$ and is realised entirely within the $\mathrm{H}$ range. Thus, the rising tone tends to be perceived as not being acute (20a-b; see Figure 6).
a. ègě "cassava"
b. ìrọlẹ̣ "evening"

There is $\mathrm{H}$-lowering in Igbomina dialect. Adeniyi (2018) argues that when $\mathrm{H}$ is preceded by $\mathrm{L}$ or the aspectual marker é (which has $\mathrm{HL}$ tonal property) and is at the same time followed by a floating $L$, it is lowered to $M(21 a-d)$. The consequence of this is that the lowering of the $\mathrm{H}$ prevents the realisation of a rising tone as should be expected from the understanding of SY tonology. If there is a linked $L$ after the lowered $H$, that $L$ also does not fall, thereby reducing the frequency of contour tones in Igbomina (see an articulation of this process for Igbomina in Adeniyi 2018).
a. ̀ gbé (i)yàwǒ $\rightarrow$ İgbeyàwǒ "wedding"
b. àbǔrô mú (ẹ)rìnlă $\rightarrow$ àbǔrô mẹrìnlă "14 younger ones"
c. à tì ní (ẹ)yìn $\rightarrow$ àtìlẹyìn "support"
d. ì dú (i)je $\rightarrow$ idije "competition" 
DS in Igbomina dialect is clearly at the stage of ALT, whereby the tone preceding the DS falls toward its offset as a reflector of the lost $L$, but the lowering attested is significant (see Figure 17).

4.5 ljebu

Just like SY, the ljebu dialect has three level tones $L, M$, and $H$, but it varies from SY in a number of ways. Unlike SY or the other dialects covered in this study, $L$ is raised in the initial position in ljebu dialect. This is irrespective of the tone that follows it, it is raised before $L(22 a-b)$, before $M(22 c)$, and before $H(22 d-e)$.
a. àgbè "farmer"
b. òdòdǒ "flower"
c. è̀fọn "mosquito"
d. àdăn "bat"
e. ẹ̀gẹ "cassava"

One way of distinguishing a raised $L$ and $a M$ is to examine the tone following each of them. A following $\mathrm{H}$ will rise after $\mathrm{L}$ (whether raised or not), but will not rise after $\mathrm{M}$. Also, a raised $L$ does not exert any effect on a following $L$, but if it is $M$, then a following $L$ is realised as a $\widehat{\mathrm{ML}}$ falling contour. The implication of this is that in addition to the $\mathrm{HHL}$ falling tones realised after $\mathrm{H}$, ljebu also has the $\mathrm{MML}$ mid-falling tone after $\mathrm{M}$. The only environment where $L$ appears without any modification is after another $L$ (whether that preceding $L$ is raised or not).

The mid-falling contour $M \widehat{M L}$ is such that $L$ following $M$ is realised as a fall beginning from the level of the preceding $M(23 a-d)$. This is so widespread in the dialect that it has significant impact on the frequency of contour tones compared to the other dialects. Figure 7 presents the pitch track of a sample word; notice the clear fall in the pitch of the L after $M$. 
(23)

$$
\mathrm{MML} \text { in ljebu }
$$

ljebu SY Gloss

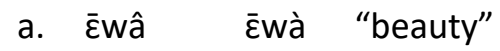
b. îkû îkùn "belly"
c. כ̄dzâ Jdzà "market"
d. ihô ihò "hole"

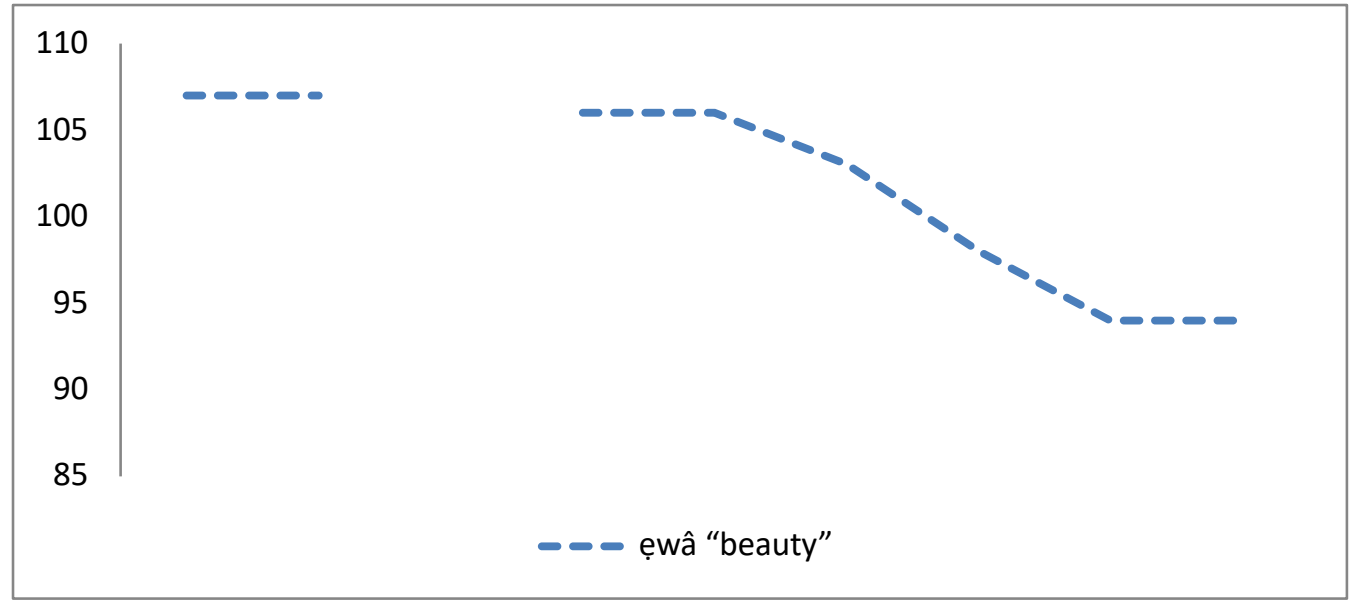

Figure 7. $\widehat{\mathrm{ML}}$ falling contour in ljebu dialect

Ghotuo and Gwari are related West Benue-Congo languages that also distinguish between falling tones in the same manner reported for ljebu. Both languages have $\widehat{\mathrm{HL}}$, and $\widehat{\mathrm{ML}}$ contours respectively, while Ghotuo further has $\widehat{\mathrm{HM}}$ falling contour (Hyman \& Magaji 1970; Elugbe 1986; Adeniyi 2015, 2017; Adeniyi \& Elugbe 2018). This indicates that although the slope dimension is rarely used in distinguishing between contour tones, Ijebu is not alone in its deployment.

The $\mathrm{H} \widehat{H L}$ falling tone is realised in environments outlined for SY (25a), but in ljebu, it only has a slight fall in pitch and is subject to levelling in the flow of speech.

The mid tone of Ijebu is similar to that of SY; it occurs in initial position (23a-d), after another mid (egugu "bone"). Beyond these, M of ljebu varies distributionally from SY. MH sequence in initial position in SY alternates with LR in ljebu (24a-e). This means that initial $\mathrm{M}$ in an $\mathrm{MH}$ sequence in SY alternates with $\mathrm{L}$ in ljebu, yielding $\mathrm{LH}$ which then triggers the formation of a rising contour tone (Figure 8). The implication of this alternation, which is not attested in any other dialect studied in this article, is that it increases the frequency of 
Dialectologia 27 (2021), 1-31.

ISSN: 2013-2247

contour tones compared to other dialects of Yoruba as well as projects a massive perceptual distinction from the other dialects.

(24) $\widehat{L} \widehat{L H}$ vs. MH alternation between ljebu dialect and SY
ljebu SY Gloss
a. àdě adé "crown"
b. àpă apá "arm"
c. ìgbǒ igbó "bush"
d. àjă ajá "dog"
e. ọ̀wọ̆ ọwọ́ hand

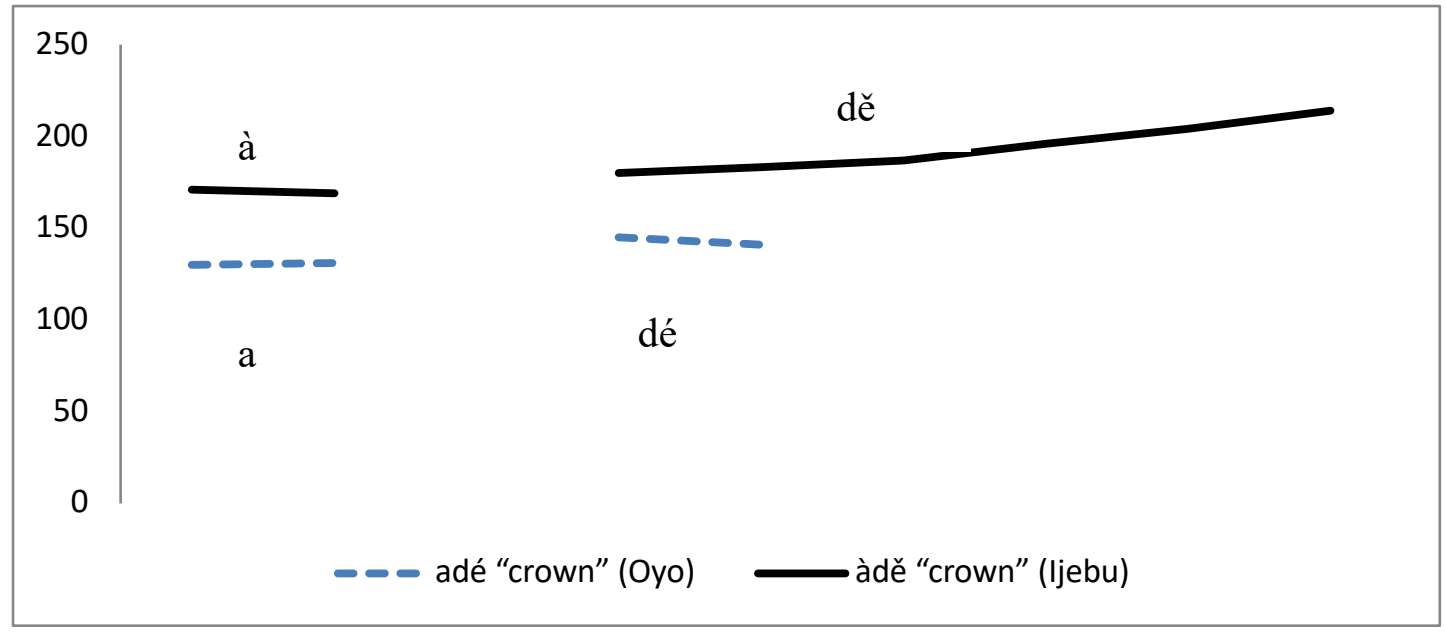

Figure 8. $\mathrm{L} \widehat{\mathrm{LH}}$ vs. MH alternation between ljebu dialect and SY

Further, in words containing more than two syllables, the rise of the $\mathrm{R}$ contour terminates within the $M$-range and it is perceived more as $M$; this perceived $M$ however triggers $\widehat{\mathrm{HL}}$ falling when it is followed by $\mathrm{L}(25 \mathrm{a}-\mathrm{c})$.
a. àlăkân "crab"
b. àbǐyá "armpit"
c. ọ̀lọ̆dẹ "hunter" 
The $\mathrm{H}$ rarely occurs without phonetic modification in ljebu dialect. The only environment where it occurs as plain $\mathrm{H}$ is in $\mathrm{H}$-toned monosyllabic verbs or $\mathrm{H}$-initial words where it is followed by $L$ (tútû "wet"). $\mathrm{H}$ is realised as a rising contour when preceded by L, just like SY. Seen in the light of SY tone system, there is no HH sequence in ljebu dialect; $\mathrm{HH}$ of SY corresponds to LH in ljebu (26a-d; Figure 9). This is another L particular to ljebu and it is phonemic in the dialect because the $L$ triggers tone spreading in such a manner that the following $\mathrm{H}$ is realised as a $\widehat{\mathrm{LH}}$ rising tone.

(26) $\widehat{L} \widehat{L H}$ vs. HH alternation between ljebu dialect and SY
ljebu
SY
Gloss
a. dùdǔ dúdú "black"
b. àbìyă abíyá "armpit"
c. bùrùkǔ burúkú "(to be) bad"
d. ègùngǔn egúngún "masquerade"

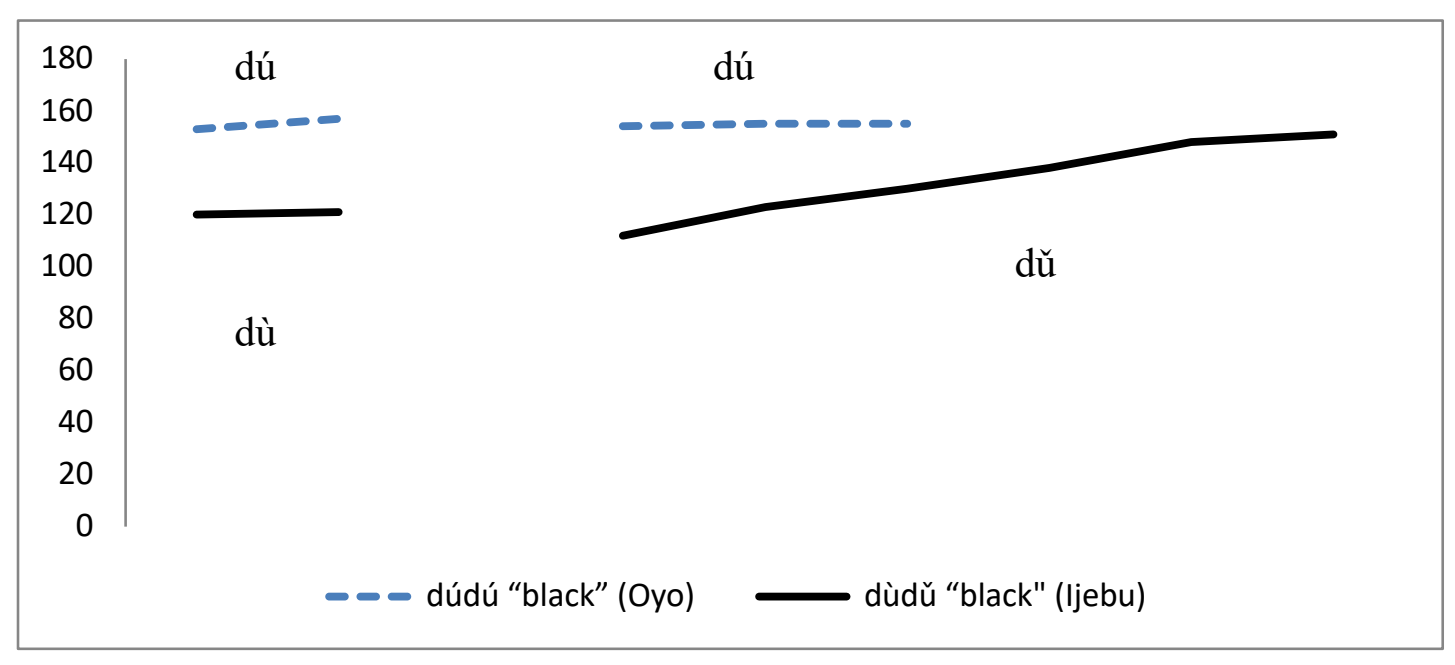

Figure 9. $\widehat{\mathrm{LH}}$ vs. HH alternation between ljebu dialect and SY

In the end, every $\mathrm{MH}, \mathrm{HH}$, and $\mathrm{ML}$ sequence of SY and the other dialects studied in this work alternates with various contour-yielding sequences in ljebu dialect. These increase the number as well as frequency of contour tones in ljebu compared to the other dialects. 


\section{6 ljesa}

To a large extent, the tone system of Ijesa is similar to that of SY. In terms of the contour tones, $\mathrm{L}$ rises after $\mathrm{H}$ and $\mathrm{H}$ falls after $\mathrm{L}$. The rising tone starts very high (deep into the $\mathrm{H}$ range), and only reaches its target within the timing of a following TBU. For instance, in $\mathrm{L}-\mathrm{H}-\mathrm{H}$ sequence, the target for $\mathrm{H}$ is only reached at the second $\mathrm{H}$. However, there is a progressive rise all through. In the normal $\mathrm{HL}$ sequence, the $\mathrm{L}$ is a slight fall realised within the range of $\mathrm{H}$. It however has notable differences from SY; for instance, where there is a floating $L$ between linked $H$ and $L(H(L) L)$, the linked $L$ does not fall (27). This is similar to the F-blocking outlined for Ife in section 3.3. Observe in Figure 10 that the linked L on the TBU -gbà- does not fall. In addition, there is a significantly wide distance between the offset of the preceding $\mathrm{H}$ on ni- and the onset of the $\mathrm{L}$ on $-g b a ̀-$ such that whatever might look like a fall is executed entirely within the L-range and is not perceptually discernible.

$$
\text { ní ìgbàgbọ̌ } \rightarrow \text { nígbàgbọ̆ "have faith" }
$$

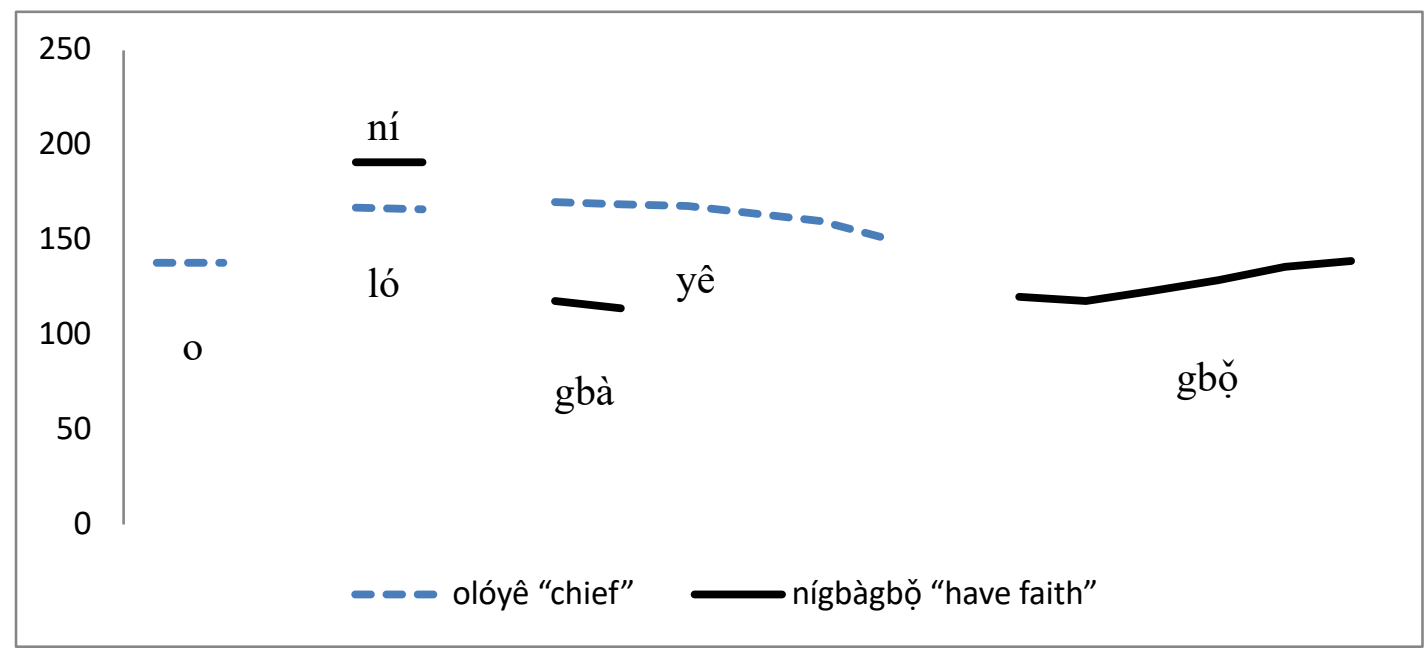

Figure 10. Falling tone vs. F-blocking in ljesa dialect

There is also $\mathrm{H}$-spreading by which $\mathrm{H}$ dislodges and replaces following non- $\mathrm{H}$ tones that are in non-final positions (28a-c). When the following tone is $L$, then $F$ is not realised. 
The $\mathrm{H}$ displaces it entirely, but in instances where the $\mathrm{L}$ is immediately followed by another $\mathrm{H}$ as is the case in (28c), that $\mathrm{H}$ is realised as a rising tone. This shows that although the $\mathrm{L}$ is displaced and rendered stranded phonetically, it still exerts some phonological effects.
a. àbǔrô mi $\rightarrow$ àbǔró mi "my younger one"
b. àlọ̆ àpamọ̀ $\rightarrow$ àlọ̆ ápamọ̀ "folktale"
c. gbẹbê gbărôyě $\rightarrow$ gbẹ́bé gbărôyě "responder to pleas and petitions"

\subsection{Ilorin}

Ilorin dialect is also similar to SY to a large extent. However, the contour tones differ in a number of notable ways. The rising contour starts very high, specifically within the $\mathrm{H}$ range and only rises slightly (29a-b; broken lines in Figure 14). Often, the rising contour is perceived more as level $\mathrm{H}$ than gliding.
a. ̣̀gẹe "cassava"
b. òdòdǒ "flower"

The falling contour in Ilorin dialect starts on a level higher than preceding $\mathrm{H}$, and continues on a largely level high pitch before dropping sharply toward the offset of the TBU. The fall still ends around the upper limit of the H-range (30a-c; Figure 13) but is very clearly perceptible and is in fact the clearest tonal marker of Ilorin dialect.
a. olóyê "chief"
b. ológbô "cat"
c. ìgbǎlûmọ̀ "cherry" 
Dialectologia 27 (2021), 1-31.

ISSN: 2013-2247

\subsection{Onko}

Although Onko dialect has the basic three tones and two contours outlined for SY, the phonetic realisations of the contour tones are significantly different from SY. The rising tone usually begins its rise from a significantly high level (usually toward the top of the $\mathrm{H}$ range) and only rises slightly. Sometimes, the rise is not perceptible (31a-c; Figure 14).
a. è̀gẹ dùn pǔpọ̀
b. èyìn ìyàwǒ kò mà nì mẹní o
c. fún tònǐ "for today"

Perceptually, the L does not fall after $\mathrm{H}$ in Onko dialect. This is consistent both in the lexical items and in larger utterances such as sentences. Although pitch tracks may suggest a slight fall in the pitch contours of $L$ after $H$ as may be seen in Figure 11, it must be emphasised that whatever fall that may be present usually starts toward the base of the L-range and is perceived entirely as L.

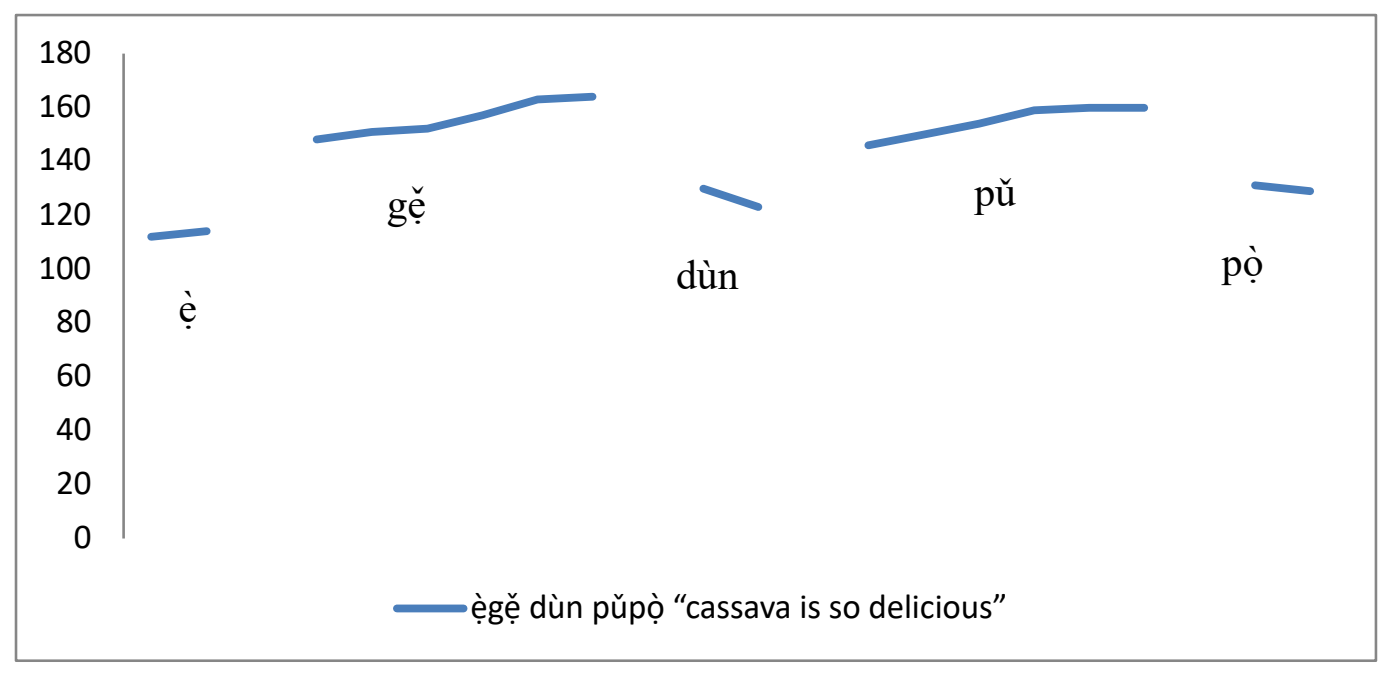

Figure 11. High onset of rising tone and non-realisation of falling tone in Onko 
The fall that usually characterises the $\mathrm{H}$ preceding DS in SY and some of the other dialects is completely absent in Onko (32a-d; See Onko in Figure 17). ${ }^{5}$ This makes DS in Onko of a classical nature, as against that of SY which has been subject of various interpretations (Bamgbose 1967; Adeniyi 2009).
a. ọlọ́un "God"
b. ìkéde "announcement"
c. orísun "source"
d. ọọ́rin "eighty'

\section{Summary and discussion}

\subsection{Summary}

Table 1 below presents a summary of the characterising features of contour tones in the eight dialects presented so far. The matrix shows that phonetically speaking, different types of falling and rising tones have been identified for the dialects under consideration. This suggests that the phonetic nuances of contour tones constitute a major mark of dialectal distinction among Yoruba dialects.

\begin{tabular}{|c|c|c|c|c|c|c|c|c|c|}
\hline 莽 & 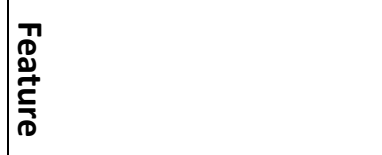 & \ৃo & 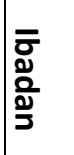 & $\overline{\mathbb{D}}$ & 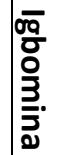 & 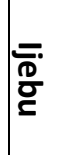 & 高 & $\frac{\overline{\bar{o}}}{\frac{1}{5}}$ & 옹 \\
\hline \multirow{8}{*}{ Rising tone } & Extreme starting point & & $\mathrm{x}$ & & & & & & \\
\hline & Normal starting point & & & $\mathrm{x}$ & & $\mathrm{x}$ & & & \\
\hline & Raised starting point & $\mathrm{x}$ & & & $\mathrm{x}$ & & $\mathrm{x}$ & $x$ & $\underline{x}$ \\
\hline & Early end point & & $\mathrm{x}$ & $\mathrm{x}$ & & & & $x$ & $x$ \\
\hline & Normal end point & $\mathrm{x}$ & & & $\mathrm{x}$ & & & & \\
\hline & Delayed target & & & & & $\mathrm{x}$ & $\mathrm{x}$ & & \\
\hline & Subject to leveling & & $\mathrm{x}$ & $\mathrm{x}$ & & & & & \\
\hline & Level in final position & $\mathrm{x}$ & $x$ & $\mathrm{x}$ & & & & & \\
\hline
\end{tabular}

\footnotetext{
${ }^{5} \mathrm{~A}$ comparison of the features is undertaken in Section 5.2.4
} 
Dialectologia 27 (2021), 1-31.

ISSN: 2013-2247

\begin{tabular}{|c|c|c|c|c|c|c|c|c|c|}
\hline Mid tone & Trigger for falling & & & & & $\mathrm{x}$ & & & \\
\hline \multirow{4}{*}{ Falling tone } & Extreme starting point & $\mathrm{x}$ & $\mathrm{x}$ & & & & & $\mathrm{x}$ & \\
\hline & Normal starting point & & & $\mathrm{x}$ & & $\mathrm{x}$ & $\mathrm{x}$ & & \\
\hline & Lowered starting point & & & & $\mathrm{x}$ & & & & \\
\hline & Normal end point & & & $\mathrm{x}$ & $\mathrm{x}$ & & & & \\
\hline & Short fall within H range & $\mathrm{x}$ & $\mathrm{x}$ & & & $\mathrm{x}$ & $\mathrm{x}$ & $\mathrm{x}$ & \\
\hline & Delayed target & $\mathrm{x}$ & & & & & & & \\
\hline & Subject to leveling & & $\mathrm{x}$ & & $\mathrm{x}$ & & $\mathrm{x}$ & & \\
\hline & No fall & & & & & & & & $\mathrm{x}$ \\
\hline
\end{tabular}

Table 1. Comparative feature matrix of contour tones in Yoruba dialects

The picture that becomes clear immediately is that some dialects clearly differ from others; ljebu, with its preponderance of contour tones where other dialects do not have is extremely distinctive in this respect. Also, Ife, Igbomina and ljesa in which contour tones are severely inhibited by high tone lowering also group themselves together on the other extreme. Within the group having high tone lowering, Ife and Ijesa further have the process of falling tone blocking by floating L. However Ife and ljesa are further distinguishable on the basis of their falling tones (Figure 16); although the falling tone starts around the same range in the two dialects, that of ljesa ends within the H-range while that of Ife glides all the way to the L-range (Figures $4,1 \& 16$ ). Close to these dialects is Onko that does not have the falling tone at all. The other dialects, namely Oyo, Ibadan and llorin are at various stages between the two extremes.

\subsection{Discussion}

Beyond the straightforward distinguishing features outlined in Section 5.1, the fine nature of the contours in each dialect reveals dialectal distinctions (See Figures 16). It is not unusual for contour tones to come in different shapes. Maddieson (1980: 129) observes that two types of rising tones or two types of falling tones are more often and more clearly distinguishable by the amount of pitch change they exhibit. As such $L$ that falls from the level of the $H$ has a larger amount of pitch change than that which falls from the level of the M. It is also possible for two contour tones to have the same amount of 
pitch change, but be located at different parts of the pitch range (Maddieson 1980: 129). Maddieson (1980: 130) reports that the "slope dimension," which corresponds to amount of pitch change, is the least relied on to distinguish between tones. For this study however, the dialects are similar in terms of average pitch (all having three tone system) and direction of pitch change (all having falling and rising contours); which leaves the variation in the slope dimension across the dialects, the location of the slope within the pitch range, and the nature of pitch curves as the core markers of dialectal variation. Thus, the dialects are further compared on the bases of these dimensions in this subsection.

\subsubsection{Slope Dimension}

In comparing the slope of contours a closer look is paid to contour tones spanning the range of at least two tones. In this case Ife and Igbomina dialects have the $\widehat{\mathrm{HL}}$ falling contour beginning on a level just below that of $\mathrm{H}$ and gliding to the level of $\mathrm{L}$; these are assumed to span beyond the range of one tone, which already distinguishes them along this line. But in spite of this similarity, Figure 12 shows that the curves differ substantially between the two dialects.

On the basis of the rising tone, both Oyo and ljebu dialects have the $\widehat{\mathrm{LH}}$ rising tone spanning more than one tone range, which distinguishes them. However, the preponderance of contour tones in ljebu already distinguishes it from Oyo and indeed other dialects. 


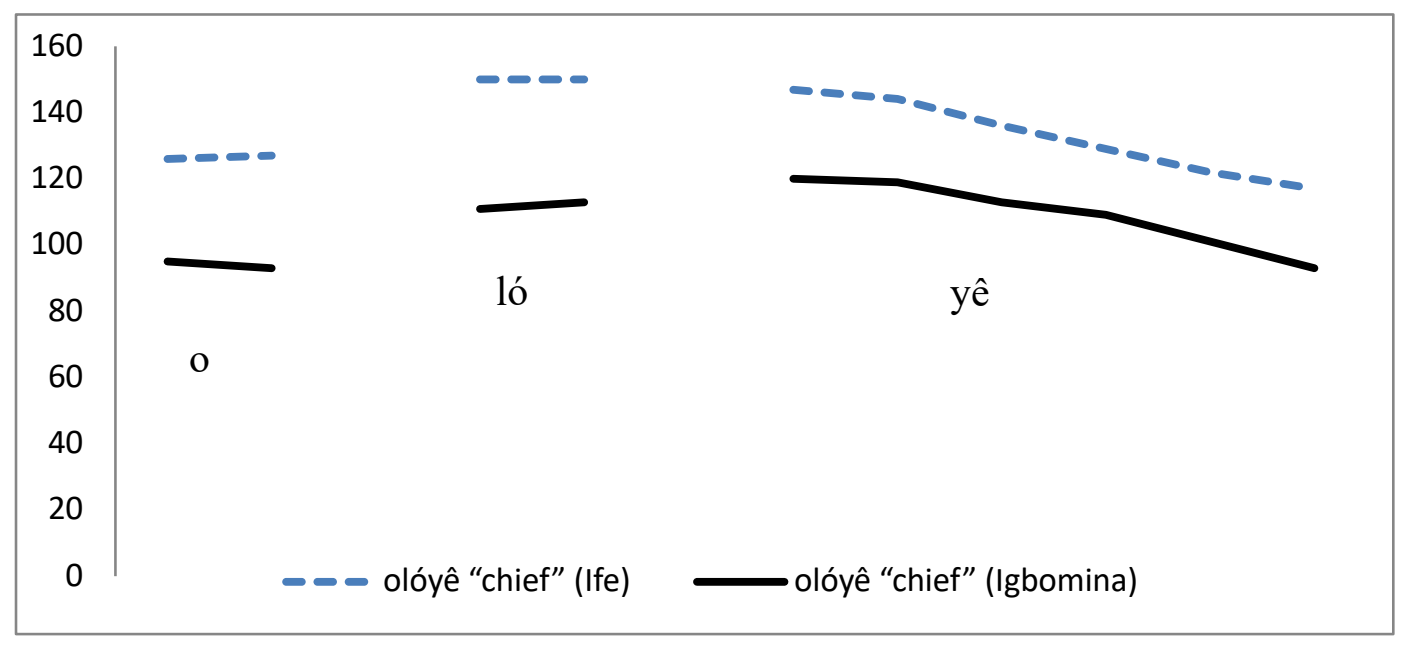

Figure 12. Falling tones in Ife and Igbomina dialects

\subsubsection{Location of Pitch Change}

In comparing on the basis of location of pitch contours, the focus is on those contours that both start and end within the range of a single tone. Incidentally, this is among the most active distinguishing features across the dialects. For the falling tone, Oyo, Ibadan, Ijebu, ljesa and Ilorin have their falling tones restricted to specific locations. But as Table 1 reveals, in Oyo, Ibadan, and Ilorin dialects, the fall begins from an extrahigh position and terminates still within the range of $\mathrm{H}$; for ljebu and ljesa dialects, the fall begins normally and terminates still within $\mathrm{H}$. The $\mathrm{L}$ does not fall after $\mathrm{H}$ in Onko dialect. Ijebu and ljesa appear to have similar characteristics, but the preponderance of contours where other dialects do not have coupled with ljesa's opposite nature of reducing contour tones via $\mathrm{H}$-tone lowering and floating $\mathrm{L}$ blocking of spreading already mark them clearly different. A pattern is emerging of closeness between Oyo, Ibadan, and Ilorin. It is worth noting that these three dialects are also close in terms of proximity, and this may be a mark of that proximity between them. Figure 13 shows the pitch curves of the falling tone in the three dialects, with the sharp final fall of llorin being most prominent and Ibadan also showing some degree of similar final fall. 


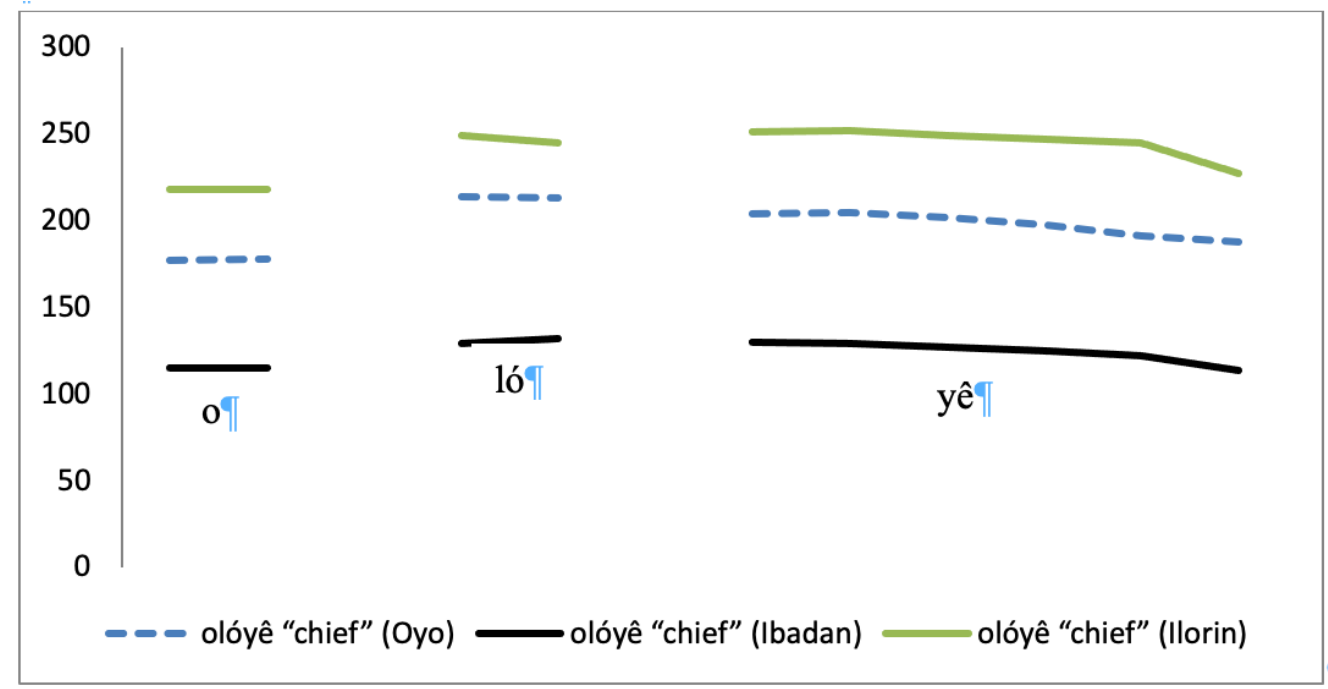

Figure 13. Falling tone in Oyo, Ibadan and Ilorin dialects

For the rising tone, Ibadan, Ife, Igbomina, ljesa, Ilorin, and Onko have their $\widehat{\mathrm{LH}}$ contours restricted to specific locations. Ibadan dialect is the only one with the rise starting on an extremely low level and is thus distinguished along that line. Here, only Ilorin and Onko share the nature of beginning at a raised level and still ending within the $L$ range. A comparison of the pitch curves for these dialects (Figure 14) shows no notable difference between these two pitch curves. For Ife, Igbomina and ljesa dialects, Figure 15 shows Igbomina differing from the others in two notable ways: the raised onset of the rise relative to the preceding $L$ and the significantly more acute degree of the rise. Ife and Ijesa, which are more closely situated geographically, tend to be quite similar.

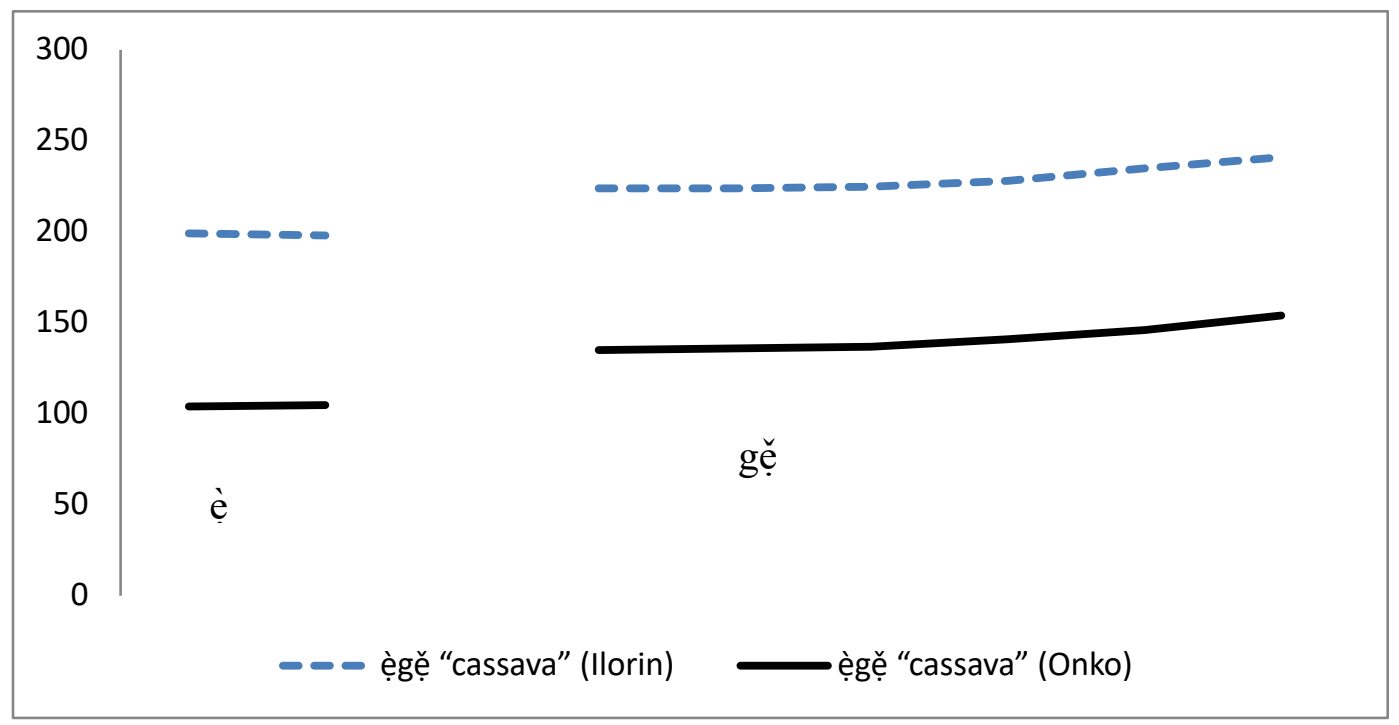

Figure 14. Rising tones in Ilorin and Onko dialects 


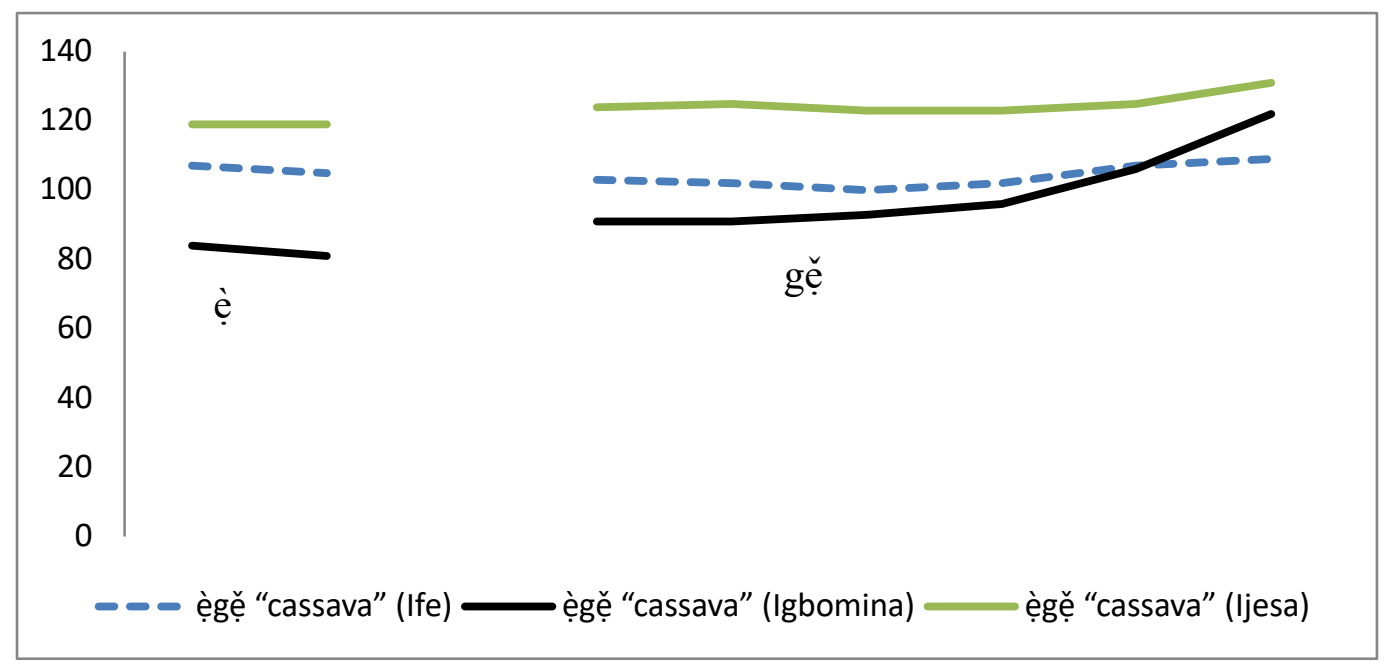

Figure 15. Rising tone in Ife, Igbomina, and ljesa dialects

\subsubsection{High Tone Lowering}

High tone lowering has been reported for three dialects, namely Ife, Igbomina, and Ijesa. It has also been reported that this phenomenon affects the realisation of contour tones significantly in the dialects because it eliminates the environment for both rising and falling contours and renders the contour tones comparatively less frequent in the three dialects. Observe in Figure 16 below that only Oyo dialect (black arrow) has rising pitch on the second TBU; the other three dialects have relatively level or even mildly falling curves. That goes on to affect the following tone which is falling for its entire duration in Oyo dialect, but again is relatively level for the other three dialects. Even in ljesa where it appears a little falling, note that the fall begins on a level significantly lower than the preceding tone and in fact within the range of $L$, thus it is not perceived as a falling tone. This thus paints a clear picture of the pronounced effects of $\mathrm{H}$-lowering on the general tonal outlook of Ife, Igbomina and ljesa dialects compared to the other dialects. 


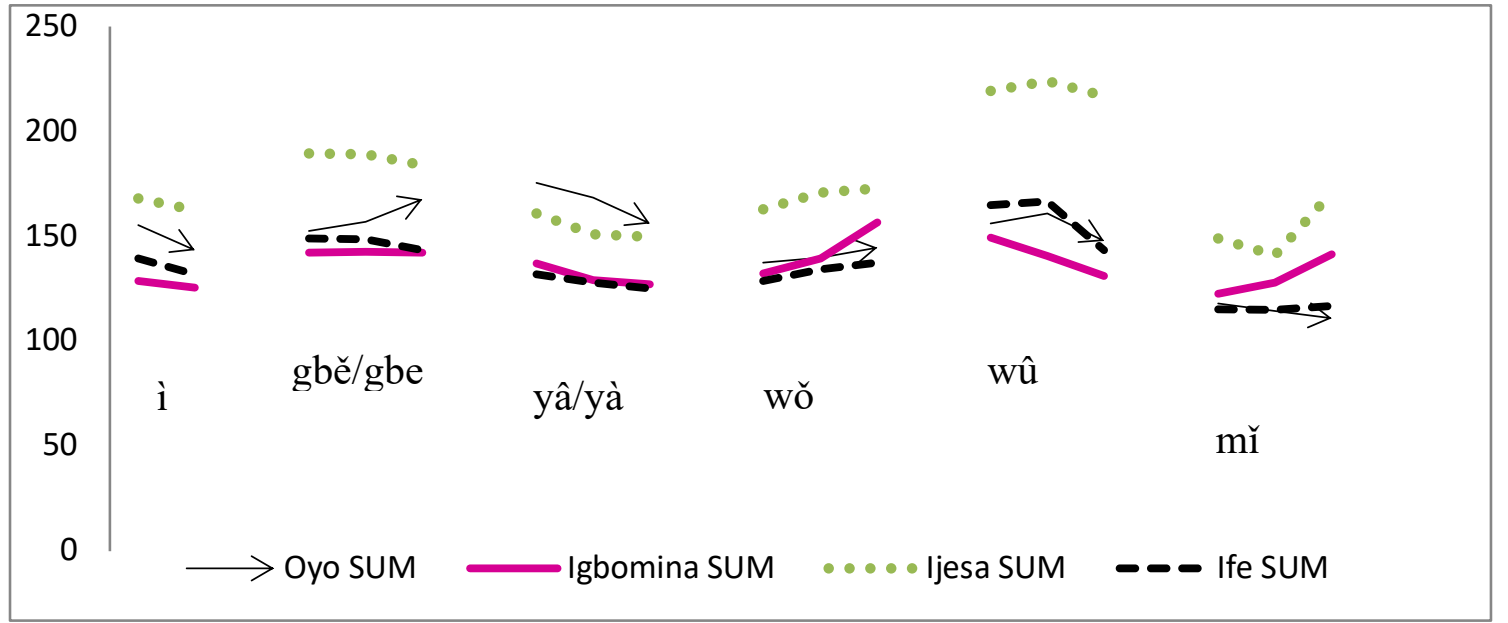

Figure 16. Comparative graph of ìgběyâwǒ wûmǐ vs ìgbeyàwǒ wûmǐ "Wedding appeals to me" across Oyo, Ife, Igbomina and ljesa dialects

\subsubsection{Pre-Downstep Falling High Tone}

It has been noted repeatedly in this work that $\mathrm{H}$ that precedes DS in Yoruba usually falls as indicator of the floating $L$ (that triggers the DS). Thus, the extent of this fall as a version of falling tone is examined across the eight dialects and the result is presented in figure 17 below. Observe in Figure 17 that for Ibadan (solid black line) and Onko (back arrow), there is no fall on the TBU rí at all. Close to these is ljesa (red circles) with very mild fall. Other dialects have different degrees and shapes for the falling pitch curve and all of these contribute to the perceptual distinction between the dialects.

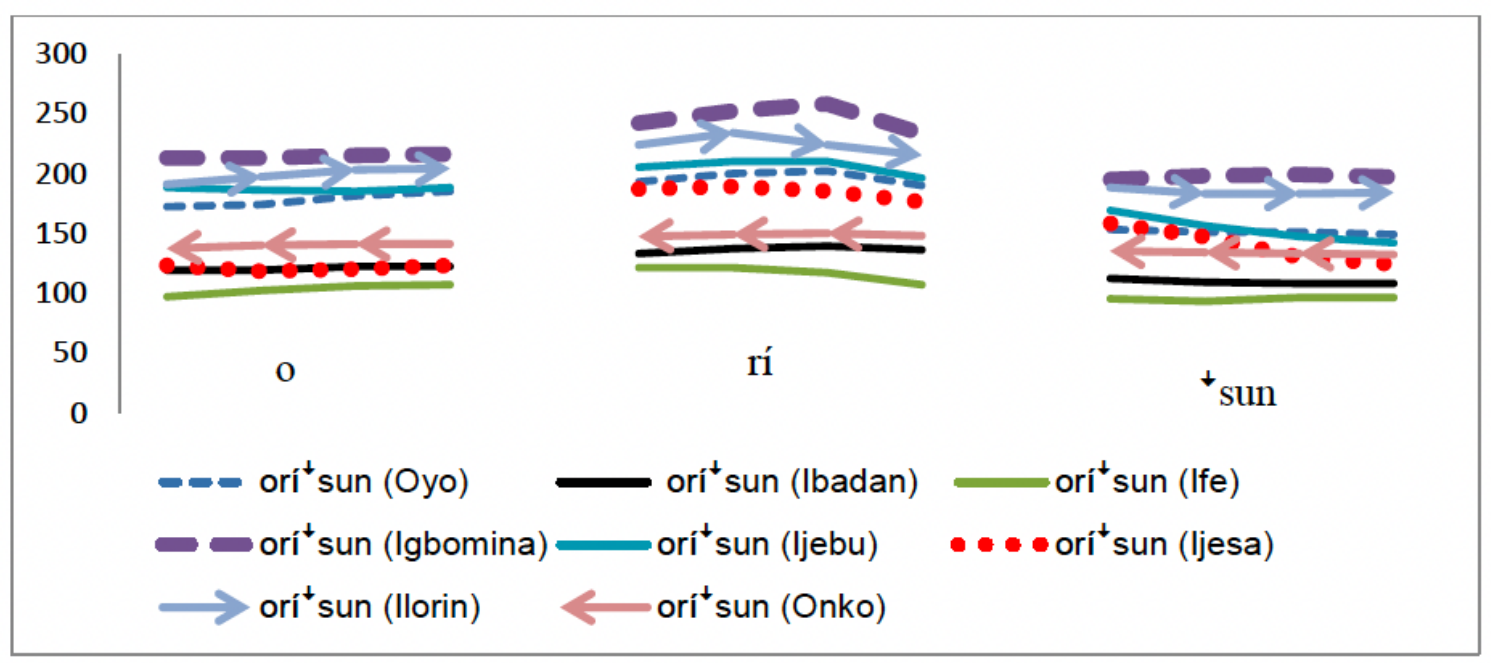

Figure 17. Comparison of pre-DS falling tone in ori $^{\dagger}$ sun "source" 


\section{Conclusion}

The perception of the dialects studied in this research as different dialects has been shown to be essentially tonal. Each dialect exploits various nuances of the available three tones, particularly pitch contours, to distinguish itself from the other dialects. Specifically, contour tones in the dialects studied have been discriminated using four basic dimensions, namely slope, location of pitch change, nature of contour, and extreme starting point. It has been shown that generally, each dialect exploits one or a combination of these dimensions to different degrees in order to distinguish itself from other dialects. This is because it has been shown that the dialects studied are similar in terms of their segmental elements as well as the average pitch levels. While ljebu further deploys multiplicity of contours including $\widehat{\mathrm{ML}}$ falling tone, Ife, Igbomina and ljesa dialects rather reduce tonal contours through the deployment of $\mathrm{H}$-lowering. Ife and ljesa further reduce the frequency of contour tones through F-blocking. Onko on its own does not use falling contour at all, which clearly distinguishes it from the other dialects.

The conclusion from here is that tone is a more prominent dialectal indicator than conventional segmental and grammatical elements. That is why even where different dialects use the same segmental and grammatical materials and structures, the differences between them are still easily identified. This work has therefore shown how central tone is to dialect identification. This makes tonalect (that is, tonal dialectology) a necessary component of the study of dialectology. It will therefore be interesting to see how an automatic dialect identification program incorporating the entire pitch functions as well as consonant-tone interaction will perform. An implication of these findings is that any work on Yoruba tone system must spell out the dialects of the speakers studied, otherwise there would be a cacophony of results due to variations in the dialects studied in different works. 


\section{References}

ADENIYI, Kolawole (2009) "The Typology of Three-Tone Systems: Ebira, Ghotuo, Yala (Ikom), and Yoruba", M.A. Project, Department of Linguistics and African Languages, University of Ibadan, Ibadan, Nigeria.

ADENIYI, Kolawole (2015) Downstep in Three-tone Systems of West Benue-Congo Languages, Ph.D. Thesis, University of Ibadan.

ADENIYI, Kolawole (2017) "The limits of perception in the tonal orthographies of three-tone systems", Linguistik Online, 84.5, 3-22. <https://bop.unibe.ch/linguistikonline/article/view/3844/5824>

AdenIYI, Kolawole \& Oluwafemi E. BAMIGBAde (2017) "Customized Ibadan-Yoruba", Linguistik Online, 80. <https://bop.unibe.ch/linguistik-online/article/view/3563/5413>

ADENIYI, Kolawole (2018) "High tone lowering in Igbomina-Yoruba", Journal of the Linguistic Association of Nigeria, Supplement III, 221-231.

AdeNIYI, Kolawole \& Ben ElUGBe (2018) "Consonant voicing, tonal morphemes, and downstep in Gwari, Linguistique et Langues Africaines, 4, 77-97. <http://www.lambertlucas.com/livre/linguistique-langues-africaines-4/>

Adetugbo, A. (1982) "Towards a Yoruba dialectology", in A. Afolayan (ed), Yoruba language and literature, Ibadan: University of Ife Press, 207-224.

AKINKUGBE, Femi (1976) "An Internal Classification of the Yoruboid Group (Yoruba, Isekiri, Igala)", Journal of West African Languages, 11 (1-2), 1-19.

AKINLABI, Akinbiyi (2004) "The sound system of Yoruba", in N.S. Lawal, M.N.O. Sadiku \& A. Dopamu (eds.), Understanding life and culture: Yoruba, NJ: Africa World Press Inc., 453-468.

AREMO, Bolaji (2012) How Yoruba and Igbo became different languages, Ibadan: Scribo Publications Ltd.

AYEOMONI, Moses Omoniyi (2011) “A lexico-syntactic exploration of Ondo and Ikale dialects of the Yoruba Language", Journal of language and culture, 2.7, 124-132.

BAMGBOSE, Ayo (1967) A short Yoruba grammar, Ibadan: Heinemann.

BAmgbose, Ayo (1990) Fonoloji ati Girama Yoruba, Ibadan: University Press Plc.

Bougrine, Soumia, Hadda CHeRroun \& Djelloul ZIADI (2018) "Prosody-based spoken Algerian Arabic dialect identification", Procedia Computer Science, 128, 9-17.

CONNELL, Bruce \& Robert D. LADD (1990) "Aspects of pitch realization in Yoruba", Phonology, 7, 1, 1-29. 
Dialectologia 27 (2021), 1-31.

ISSN: 2013-2247

ElugBe, Ben O. (1986) "The analysis of falling tones in Ghotuo", in K. Bogers, H. van der Hulst \& M. Mous (eds.), The phonological representation of suprasegmentals, Dordrecht-Holland, Cinnaminson-USA: Foris, 51-61.

Etman, A \& A. A. Beex (2015) "Language and dialect identification: a survey", Proceedings of SAI Intelligent Systems Conference, London, UK, 220-231. New York: IEEE.

FabunMI, Felix Abidemi (2013) "Negation in sixteen Yoruba dialects", Open journal of modern linguistics, 3, 1-8.

<https://www.scirp.org/pdf/OJML_2013032915274281.pdf>

FRIEDMAN, Victor A. (2017) "Seven varieties of Arli: Skopje as a center of convergence and divergence of Romani dialects", Romani Studies, 5. 27, 29-45.

HARAGUCHI, Shosuke (1979) The tone pattern of Japanese: an autosegmental theory of tonology, Doctoral dissertation, M.I.T.

HYMAN, Larry M. \& Daniel J. MAGAJI (1970) Essentials of Gwari grammar, Ibadan: Institute of African Studies' occasional publication, 27.

LAMIDI, Mufutat Temitayo (2002) "The Tone as a Negative Marker in ljesa Sentences", Poznan Studies in Contemporary Linguistics, 38, 89-101.

LA Velle, Carl R. (1974) "An Experimental Study of Yoruba Tone", Studies in African Linguistics, Supplement, 5, 185-194.

MADDIESON, Ian (1980) "Dimensions of tone systems", UCLA working papers in phonetics, 51, 127131.

LANIRAN, Yetunde O. (1992) "Intonation in Tone Languages: The phonetic Implementation of Tones in Yoruba", Ph.D. Dissertation, Cornell University.

LANIRAN, Yetunde O. \& G. N. CLEMENTS (2003) “Downstep and high raising: interacting factors in Yoruba tone Production", Journal of Phonetics, 31, 203-250.

<https://www.sciencedirect.com/science/article/pii/S0095447002000980>

OlumuYIWA, Temitope (2009) "The high tone syllable in central Yoruba dialects", Nordic Journal of African Studies 18.2, 129-137.

<http://www.njas.helsinki.fi/pdf-files/vol18num2/olumuyiwa.pdf)>

OYETADE, Solomon Oluwole (2011) "The Yoruba language in Diaspora: lessons from the English language", Yoruba: Journal of the Yoruba Studies Association of Nigeria, 6 (5), 1-24.

YIP, Moira Jean Winsland (1980) “The Tonal Phonology of Chinese", Ph.D. Dissertation, Massachusetts Institute of Technology. 